International Journal of Biology, Pharmacy and Allied Sciences (IJBPAS)

'A B Bridge Betuen Caboratory and QRando'

WwW.iibpas.com

\title{
BIOLOGICAL ACTIVITIES OF PHILIPPINE ETHNOTOXIC PLANTS
}

\section{KHRISTINA G. JUDAN CRUZ ${ }^{1 *}$, CRISADINE MILETTE S. GABRIEL ${ }^{1}$ AND} EVARISTO A. ABELLA ${ }^{1}$

${ }^{1}$ Department of Biological Sciences, Central Luzon State University, Science City of Munoz, Nueva Ecija, Philippines

*Corresponding author: Khristina G. Judan Cruz: E-mail: karenjudancruz@gmail.com

Received $2^{\text {nd }}$ Jan. 2017; Revised 26 ${ }^{\text {th }}$ Jan. 2018; Accepted $2^{\text {nd }}$ Feb. 2018; Available online $1^{\text {st }}$ May 2018

DOI: https://doi.org/10.31032/IJBPAS/2018/7.5.4430

\section{ABSTRACT}

Given the Philippines' rich biodiversity, exploring the potential of untapped plants such as ethnobotanicals is of the essence. This study determined the antibacterial, antiinflammatory and analgesic properties of the following ethnotoxic plants of the Igorot community from Barangay Imugan, Santa Fe, Nueva Vizcaya: Cestrum nocturnum, Derris elliptica, Pittosporum pentandrum, Oreocnide trinervis and Lipang daga (local name). Disc diffusion assay was used in testing the antibacterial activity of the plants on Escherichia coli and Staphylococcus aureus while Carrageenan-Induced Edema Assay and Acetic AcidInduced Writhing Assay were used for the evaluation of anti-inflammatory and analgesic properties. Two extraction methods were used for antibacterial tests namely methanol and hot water extraction. Methanol extracts of $O$. trinervis and $C$. nocturnum showed the highest antibacterial activity against E.coli and S.aureus. P. pentandrum and C. nocturnum showed the highest percent inhibition for the anti-inflammatory test as well as the highest percent reduction of pain in the analgesic test.

Keywords: ethnotoxic, antibacterial, anti-inflammatory and analgesic

\section{INTRODUCTION}

The Philippines is a large archipelago that hosts an immense plant biodiversity and ranks fifth in the number of plant species and maintains $5 \%$ of the world's flora [1]. The country's biodiversity is one of the worlds richest that includes 9,250 species of vascular plants, one third of which are endemic [2]. This 
high endemism covers at least 25 genera of plants and 49 percent of terrestrial wildlife [1]. This richness in biodiversity and endemism holds a vast potential to discover more drugs from plants that are yet to be studied. Plants with pharmacological potential represent a vast source of therapeutic substances that can be applied for the treatment of various diseases.

In recent years, great interest has shown the discovery of plant-derived compounds with the screening and evaluation of plants to discover their biological activities for possible isolation and characterization of active components for applications in drug development. Still, many plants are still unexplored. Most of these untapped plants are those that are geographically isolated and usually wild, most of which are utilized by the ethnic indigenous groups. The last 25 years have witnessed the dramatic increase in the practice of alternative medicine [3]. This increase is in response to World Health Organization's directives culminating in several pre-clinical and clinical studies that have provided the scientific basis for the efficacy ofplants used in folk medicine to treat infections [4] [5].

Researches on the medicinal plants used by indigenous groups have increased, gaining popularity in the field called ethnobotany. Indigenous groups have their own knowledge and cultural practices on the healing capacity of these plants. Aside from medicinal plants, ethnic people also identified and use poisonous plants which are also of medicinal value [6] that are mostly not common. With the collaboration of researchers and indigenous groups, literally thousands of phytochemicals were discovered from plants and accounted as safe and effective alternatives with less adverse effects. These ethnotoxic plants in the study had already shown several biological activities such as anticancer, antimicrobial, anti quorum sensing, antioxidant, antidiabetic, and antigout (personal communication, Judan Cruz 2015).

\section{MATERIALS AND METHODS}

\section{Collection of Plant Samples}

Ethnotoxic plants evaluated in the study were pre-selected during a previous ethnobotanical survey [7] at Barangay Imugan, Santa Fe, Nueva Vizcaya. These were Cestrum nocturnum, Pttosporum pentandrum, Oreocnide trinervis, Lipang Daga (Local name; no known scientific name) and Derris elliptica.

\section{Methanolic Extraction}

Thirty grams of dried pulverized leaves of plant were mixed with $500 \mathrm{ml}$ of $20 \%$ methanol resulting to $60 \mathrm{~g}$ dry $\mathrm{wt} / \mathrm{L}$ each. The dried powder suspension was mixed for $12 \mathrm{~h}$ at room temperature and was 
filtered. The residual methanol was removed using a rotary evaporator and was kept at $4^{\circ} \mathrm{C}$ until subsequent procedures [8].

\section{Hot Water Extraction}

Fifteen grams of powdered plants were dissolved and boiled in 1 liter of distilled water for 15 mins and was filtered using filter paper. The extract was kept at 4 ${ }^{\circ} \mathrm{C}$ until subsequent procedures.

\section{Antibacterial Property of Ethnotoxic}

Plants Against $E$. coli and $S$. aureus Using Hot Water and Methanol Extracts

\section{Preparation of Test Organism}

Pure culture of $S$. aureus and E. coli were obtained from the Department of Biological Sciences, Central Luzon State University, Philippines. Nutrient broth was used in reinoculation of E.coli and S.aureus and incubated for 24 hours at $35^{\circ} \mathrm{C}$. After 24 hours of incubation, the turbidity of broth culture was adjusted in comparison with $0.5 \mathrm{Mc}$ Farland standard (with approx. $1.5 \mathrm{x}$ bacterial cells $/ \mathrm{ml}$ ) by diluting it with distilled water. The adjusted bacterial broth cultures were used for seeding the agar plates.

\section{Preparation of Agar Plates}

In the preparation of Mueller Hinton Agar, 19 grams of medium was suspended in $500 \mathrm{ml}$ distilled water. It was mixed until the mixture was homogeneous. It was sterilized at15 psi at 121 for 15 minutes. After sterilization, the agar was plated in sterilized petri plates and allowed to solidify. The agar was used for the seeding of disc extracts.

\section{Seeding of Discs with Extracts}

Discs measuring $6 \mathrm{~mm}$ were used. Distilled water served as negative control while Streptomycin sulfate was used as positive control. The discs containing the treatments: hot water extracts (HWE), methanolic extracts (ME), positive and negative control, were seeded equidistantly using sterile forceps. Separate forceps were used in seeding each disc in plates. Using a disposable cotton swab, $0.1 \mathrm{ml}$ of bacterial suspension adjusted to $0.5 \mathrm{Mc}$ Farland Turbidity Standard (1.5x cells $/ \mathrm{ml})$ was spread on Mueller Hinton agar plates. Three replications were prepared. Zone of inhibition was measured using a vernier caliper from 12 hours to 24 hours of incubation.

\section{Testing of Animals}

Tests were done on animals following the Institutional Animal Care and Use Committee (IACUC) policies, procedures and guidelines [9].

Carrageenan-Induced Edema Assay for Anti-Inflammatory Activity

Carrageenan-induced paw edema model [10] with modifications was used for evaluating anti-inflammatory property of ethnotoxic plants HWE. One capsule of Celecoxib was used as the positive control 
by dissolving in 1 milliliter distilled water and. Another 0.25 grams agarose was dissolved in $12.5 \mathrm{ml}$ saline solution and was used as inflammatory agent.

Forty five albino mice of either sex, weighing $50 \mathrm{~g}-60 \mathrm{~g}$ were used in the study. The animals were acclimatized in a cage for two weeks prior to the experiments. All the animals were provided with commercially available mice pellet diet and water. The animals were divided into seven groups. Each group of mice was given orally with $0.5 \mathrm{ml}$ of Distilled Water (control), P. pentandrum HWE, Cestrum nocturnum HWE, D. elliptica HWE, $O$. trinervis HWE, Lipang Daga HWE and Celecoxib (+ control).

The time of treatment for each animal was recorded. The initial volume of the right paw of the mouse was measured by water displacement method using a onemillimeter syringe tube. The tube was filled with water up to the $0.5 \mathrm{ml}$ mark and right paw of the mouse was dipped in the tube. The volume of the right hand paw was measured by the volume increased of water.

One hour after the above treatment, 0.2 $\mathrm{ml}$ of agar agar stock solution was injected intradermally to the right hand paw of each mouse. Details were noted such as time of treatment; measurement of the volume of the right hand paw after 3 hours and the \% inhibition were computed.

\section{Acetic Acid-Induced Writhing Assay For Analgesic Activity}

Acetic acid-induced writhing assay model [11] with modifications was used for evaluating the analgesic property of ethnotoxic plants hot water extracts. One capsule of celecoxib was dissolved in 1 milliliter distilled water and used as positive control.

Forty five albino mice of either sex, weighing $50-60 \mathrm{~g}$ were used in the study. The animals were acclimatized in a cage for two weeks prior to the experiments. All the animals were provided with commercially available mouse pellet diet and water. The animals were divided into seven groups and were administered orally with $0.5 \mathrm{ml}$ of distilled water (- control), $P$. pentandrum HWE, C. nocturnum HWE, D. elliptica HWE, O. trinervis HWE, Lipang Daga HWE and Celecoxib (+ control).

Thirty minutes after the above treatments, 0.05 milliters of $0.7 \%$ acetic acid per 50-60 gram rats was injected intraperitoneally to all rats. Three minutes after acetic acid injection, the squirms of each mouse was counted for 15 minutes. The percent of reduction in squirms was computed. 


\section{Statistical Analysis}

Analysis of the data was done using the one-way Analysis of Variance (ANOVA) followed by the Duncan multiple range test. The $\mathrm{P}$ value $<0.05$ was considered significant in all cases.

\section{RESULTS AND DISCUSSION}

\section{Antibacterial Testing}

Hot Water Extract (HWE) of Ethnotoxic

Plants Against Escherichia coli

Hot water extracts (HWE) of test plants showed zones of inhibition with $C$. nocturnum having the highest mean value of $12.93 \mathrm{~mm}$ followed by $O$. trinervis $(10.60 \mathrm{~mm})$. Meanwhile, P. pentandrum $(7.24 \mathrm{~mm})$, Lipang daga $(6.07 \mathrm{~mm})$ and $D$. elliptica $(6.01 \mathrm{~mm})$ had the least value comparable to negative control. Results also showed that effectivity of the plant extracts against $E$. coli did not diminish up to 24 hours.

\section{Methanolic Extract (ME) of Ethnotoxic} Plants Against Escherichia coli

After 12 hours of incubation, $O$. trinervis $\mathrm{ME}$ had the highest zone of inhibition with mean value of $16.33 \mathrm{~mm}$ followed by $C$. nocturnum $(15.06 \mathrm{~mm}), P$. pentandrum $(12.92 \mathrm{~mm})$ and Lipang daga $(10.06 \mathrm{~mm})$. It can be noted that the zone of inhibition did not diminish up to 24 hours.

Hot Water Extract (HWE) of Ethnotoxic Plants Against Staphylococcus aureus

After 12 hours of incubation, $C$. nocturnum HWE recorded the highest zone of inhibition with mean value of $10.55 \mathrm{~mm}$ which is comparable to positive control. Meanwhile, $O$. trinervis (6.27) $\mathrm{mm}$ and $D$. elliptica (6.18) $\mathrm{mm}$ were comparable to the negative control. It can also be observed that after 24 hours incubation, antibacterial activity did not diminish.

\section{Methanolic Extract (ME) of Ethnotoxic} Plants Against Staphylococcus aureus

C. nocturnum had the highest zone of inhibition with mean value of $12.78 \mathrm{~mm}$ while $O$. trinervis had the least value of $7.08 \mathrm{~mm}$. It can be observed that after 24 hours incubation, the zone of inhibition did not diminish. The methanol extracts of plants showed antibacterial activity except for O. trinervis.

Anti-Inflammatory Property of the Ethnotoxic Plants in Mice

Mice given with Celecoxib (+ control) got the highest inhibition of $83.33 \%$, followed by $P$. pentandrum HWE (66.67\%), C. nocturnum HWE(62.50\%), O. trinervisHWE (58.33\%), D. elliptica HWE(45.83\%), and Lipang daga HWE (41.67\%).

$P$. pentandrum and $C$. nocturnum antiinflammatory testing revealed comparable activity to Celecoxib (+ control) with mean values of $0.22 \mathrm{ml}, 0.25 \mathrm{ml}$, and $0.26 \mathrm{ml}$. $O$. trinervis HWE and D. elliptica HWE were also comparable to each other with mean values of $0.32 \mathrm{ml}$ and $0.33 \mathrm{ml}$. D. elliptica 
HWE with mean value of $0.36 \mathrm{ml}$ was comparable to the negative control $(0.40$ $\mathrm{ml})$. Statistical analysis revealed significant differences on the total percent inhibition of treatments. $P$. pentandrum and $C$. nocturnum obtained the highest percent of inhibition among the five ethnotoxic plants.

\section{Analgesic Property of Ethnotoxic Plants} in Mice

Mice given with Celecoxib (+ control) yielded the highest reduction on the number of squirms (87.94\%). Comparable results between $P$. pentandrum HWE (65.15\%) and $C$. nocturnum HWE (62.54\%) were observed.O. trinervisHWE (52.45\%) and D. elliptica HWE (49.52\%) were also comparable. Lipang daga HWE $(27.04 \%)$ had the lowest percent reduction. $P$. pentandrum HWE and C. nocturnum HWE were comparable to each other with mean values of $21.40 \%$ and $23.00 \%$ respectively. D. elliptica HWE (29.20) and O. trinervis HWE (31.00) also showed comparable results. Lipang daga HWE is significantly different from the other treatments with a mean value of $44.80 \%$. This experiment on analgesic property showed that $P$. pentandrum also obtained the highest reduction in the number of squirms among the five ethnotoxic plants tested.

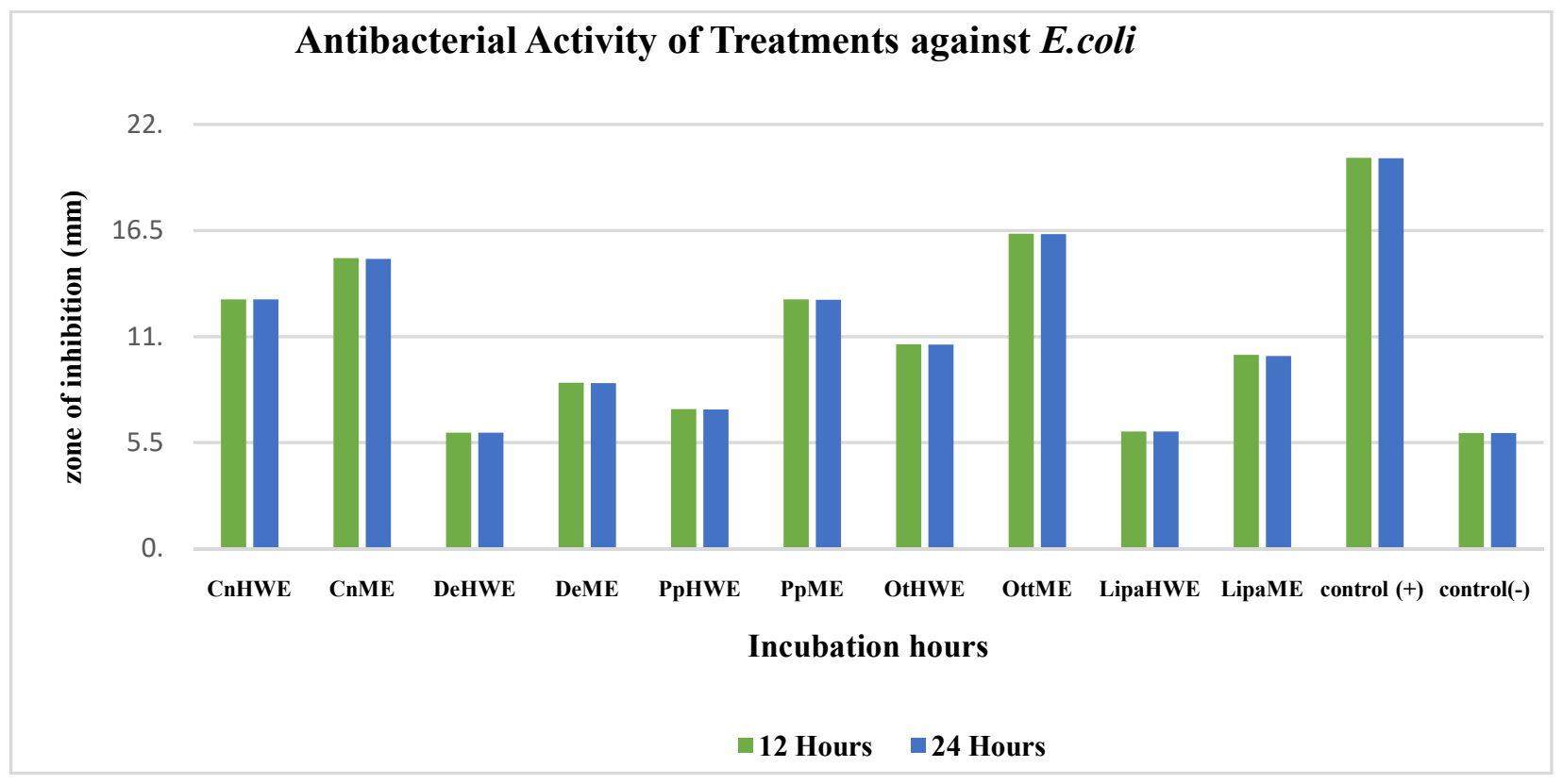

Figure 1: Antibacterial activity of HWEs and MEs against $E$.coli from 12 to 24 hour of incubation. Left to right: $C$. nocturnum HWE, C. nocturnum ME, D. elliptica HWE, D. elliptica ME, P. pentandrum HWE, P. pentandrum ME, $O$. trinervis HWE, $O$. trinervis ME, Lipang daga HWE, Lipang daga ME, positive control and negative Control 


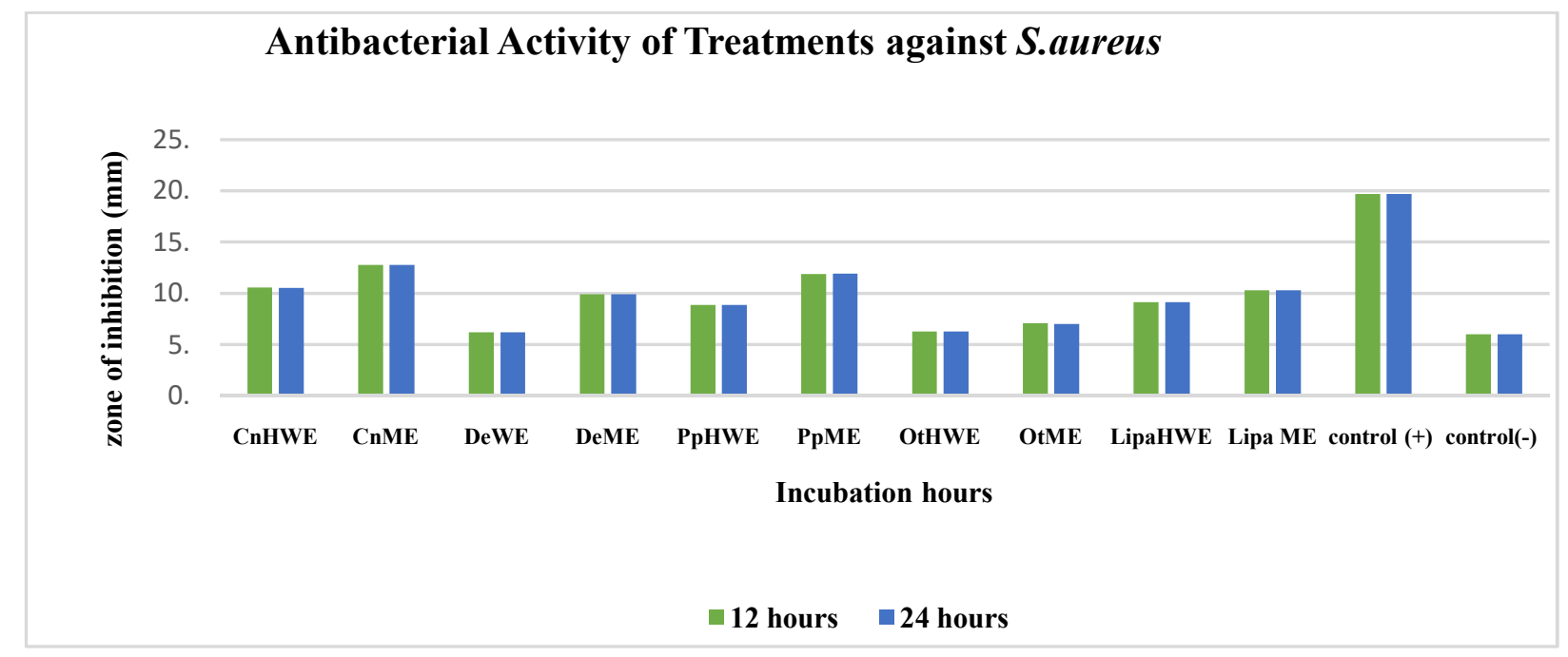

Figure 2: Antibacterial activity of HWEs and MEs against S.aureus from 12 to 24 hours of incubation. From left to right: $C$. nocturnum HWE, $C$. nocturnum ME, D. elliptica HWE, D. elliptica ME, P. pentandrum HWE, P. pentandrum ME, O. trinervis HWE, O. trinervis ME, Lipa HWE, Lipa ME, Positive control and Negative Control

DISCUSSION

The ethnobotanical survey on Brgy. Imugan, Santa Fe, Nueva Vizcaya, revealed that $C$. nocturnum is used as a piscicide [7]. Some plant guides describe $C$. nocturnum as toxic and warn that ingesting plant parts, especially the fruitmay result in elevated temperatures, rapid pulse, excess salivation and gastritis [12]. Phytochemical screening on $C$. nocturnum [13] showed that itcontains alkaloids, saponins and terpenoids. Extracts from plants containing toxic

alkaloids, such as aconitine and tubocurarin e, were used since antiquity for poisoning arrows. The antibacterial activity of $C$. nocturnum may be attributed to these components. The leaves of $C$. nocturnum have also shown significant analgesic and bactericidal activity [14] [15]. C.nocturnum also contains two flavonoid glycosides and seven steroidal saponins [16].C. nocturnum have terpenoids that are used extensively for their aromatic qualities. They play a role in herbal remedies and are under investigation for antineoplastic and other pharmaceutical functions [17].

Extracts from the bark of $P$. pentandrum tree have also shown antibacterial, antifungal and anti-inflammatory properties [18]. Phytochemical screening on $P$. pentandrum [13] also showed the plant to contain alkaloids and saponins. In plants, saponins may serve as anti-feedants, and to protect the plant against microbes and fungi [19]. The antibacterial activity of $P$. pentandrum ethanol and acetone extracts also showed partial antibacterial effect against E.coli and S.aureus [13].

As with the other plants, the ethnic community also utilize $D$. elliptica as a piscicide.D. elliptica extracts contain rotenone, a natural insecticide. Rotenone is 
classified by the World Health Organization as moderately hazardous. It is mildly toxic to humans and other mammals, but extremely toxic to insects and aquatic life, including fish. Phytochemical screening on D. elliptica [13] showed the plant to contain tannins and alkaloids. The tannin compounds are generally found in many species of plants, where they play a role in protection from insects pests [20], predation and exhibited other biological activities such as cardioprotective, antiinflammatory, anti-carcinogenic, antiviral, and antibacterial properties [21].

O. trinervis and Lipang Daga are also utilized as a piscicide by ethnic community of Imugan [7]. However, the plants remain undocumented with no available literatures and limited published scientific studies.

These phytochemicals found in these plants such as alkaloids, tannins, saponins and terpenoids possess antibacterial properties making them potential sources in the development of drugs.

\section{CONCLUSION}

The ethnotoxic plants of the Igorot community in Imugan, Santa Fe, Nueva Vizcaya, showed biological activities such as inhibition of bacteria and reduction of pain and inflammation. Hence, these ethnotoxic plants show potential and may be tapped for drug development. More researches should be conducted to further evaluate the pharmacological potential of these plants.

\section{ACKNOWLEDGEMENT}

The authors would like to acknowledge the permission and assistance of the people of Imugan, Sta. Fe, Nueva Vizcaya, Philippines. This piece of work is dedicated to them.

\section{REFERENCES}

[1] MAYUGA J. (2014). Managing Philippine Islands' Biodiversity. Business Mirror. https://businessmirror.com.ph.

[2] CONSERVATION

INTERNATIONAL.

Biological diversity in the Philippines. Retrieved from http://www.eoearth.org/view/article/ 150648

[3] RIOS JL, and RECIO MC. (2005). Medicinal plants and antimicrobial activity.J Ethnopharmacol. 2005 Aug 22;100(1-2):80-4.

[4] VIJAYA, K., AND ANANTHAN S. (1997). Microbiological screening of Indian medicinal plants with special reference to enteropathogens. J. Altern. Complement Med. 3:13-20.

[5] DILHUYDY, J. (2003). Patients attraction to complementary and alternative medicine (CAM): a reality which physicians can neither 
ignore nor deny. Bull. Cancer. 90:623-628.

[6] PARVEEN, S., DAS, S., KUNDRA， C., PEREIRA， B. (2003). A comprehensive evaluation of the reproductive toxicity of Quassiaamara in male rats.Reprod Toxicol. 2003 Jan-Feb;17(1):45-50.

[7] UNDAN, J. R., CRUZ, K. J., GANDALERA, E. E., ABELLA, E. A., DAVID, E. S., VALENTINO, M. J. G. and R. G. REYES. (2014). An Ethnobotanical Expedition of Plants With Pharmacological Potential Used by the Igorot Tribe of Imugan, Sta. Fe, Nueva Vizcaya, Philippines. Central Luzon State University, Science City of Muñoz, Nueva Ecija.

[8] REZAEI, A., GHAHROUD, R., KHORSAND, A., YAGHOOBEE, S., SOLEIMAIN, S., ROKN, A., PAKNEIAD, M., MOSLEMI, N. (2013).Methanol extracts of Salvadora persica control periodontitis by quench of quorum sensing; Romanian Journal of Biochemistry 01/2014; 51(1):43-55

[9] Institutional Animal Care and Use Committee (IACUC) Guidebook. 2002. Office of Laboratory Animal Welfare and Applied Research
Ethics National Association. Marky Pitts, Ed. $2^{\text {nd }}$ ed.

[10] WINTER, C., RISLEY, E., NUSS, G. (1982). Carrageenan induced edema in hind paws of the rats as an assay for anti-inflammatory drugs. Proceedings of the Society for Experimental Biology and Medicine; 111: 544-557.

[11] AHMED, M., SHIKHA H., SADHU, S., RAHMAN, M., DATTA, B. (2001). Analgesic, diuretic, and anti-inflammatory principle from Scoparia dulcis. Pharmazie, 56(8): 657-660.

[12] CHAN, TY. (2009). Aconite poisoning. Clinical

Toxicology 47 (4): 279285.

[13] ESPIRITU, H, ABELLA E.and PARAYAO, A.M. (2014). Antibacterial assay, Cytotoxicity Testing and Phytochemical Screening of Selected Ethnotoxic Plants Collected at Mt. Imugan, Santa Fe, Nueva Vizcaya. Department of Biological Sciences, College of Arts and Sciences, Central Luzon State University, Science City of Muñoz, Nueva Ecija, Philippines.

[14] HUANG, LG., ZHANG, XC., XIAO, H., AND ZENG, J.(2006). Analgesic effect of Cestrum 
nocturnum L. extract on mice; Chin. J. Clin. Rehab., 10: 172-174.

[15] BHATTACHARJEE, I., AND CHANDRA, G. (2007). Bactericidal Activities of Some Common Herbs in India; Pharm. Biol., 45: 350-354

[16] MI MAKI ,Y., WATANABE, K., ANDO, Y., SAKUMA, C., SASHIDA,Y., FURUYA, S., SAKAGAMI, H. (2001). Flavonol Glycosides and Steroidal Saponins from the Leaves of Cestrum nocturnum and their cytotoxicity $\mathrm{J}$. Nat. Prod., 64: 17-22.

[17] AYOOLA, (2008). Phytochemical Screening and Antioxidant Activities of Some Selected Medicinal Plants Used for Malaria Therapy in Southwestern Nigeria. Tropical Journal of Pharmaceutical Research 7 (3): $\quad$ 1019-1024. Retrieved 18 September 2014.

[18] KHARE, C. (2007). Indian Medicinal Plants, An illustrated
Dictionary. Springer-Verlag, Berlin, 2007: 496.

[19] FOERSTER, H. (2006). MetaCyc Pathway: saponin biosynthesis I. SRI International, 333 Ravenswood Avenue, Menlo Park, CA.

[20] WAR, A. R., PAULRAJ, M. G., AHMAD, T., BUHROO, A. A., HUSSAIN, B., IGNACIMUTHU, S., and SHARMA, H. C. (2012). Mechanisms of plant defense against insect herbivores. Plant Signaling \& Behavior, 7(10), 1306-1320.

http://doi.org/10.4161/psb.21663.

[21] REDONDO, L. M., CHACANA, P. A., DOMINGUEZ, J. E., and FERNANDEZ MIYAKAWA, M. E. (2014). Perspectives in the use of tannins as alternative to antimicrobial growth promoter factors in poultry. Frontiers in Microbiology, $\quad 5, \quad 118$. http://doi.org/10.3389/fmicb.2014. 00118. 